\title{
Contrastive Rhetoric in Context: A Dynamic Model of L2 Writing
}

\author{
Paul Kei Matsuda \\ Purdue University
}

\begin{abstract}
The notion of contrastive rhetoric was first proposed as a pedagogical solution to the problem of L2 organization, and the subsequent development in research has generated, among other valuable insights, three explanations for the organizational structures of $L 2$ texts, including linguistic, cultural, and educational explanations. However, the contribution of contrastive rhetoric to the teaching of ESL writing has been limited because of the underlying assumptions that has guided the early pedagogical approaches. This study identifies a static theory of L2 writing that has been widely used in teaching organizational structures and considers how the pedagogical application of insights from contrastive rhetoric studies have been limited by this theory. To overcome the limitations of the static theory, an alternative model of $L 2$ writing is proposed, and its implications for further research and the teaching of $L 2$ writing are discussed.
\end{abstract}

Originally proposed by Kaplan (1966) as a pedagogical solution to the problem of L2 organizational structures, contrastive rhetoric has seen a significant growth as a field of inquiry. In the last three decades, several books have been published (i.e., Connor, 1996; Connor \& Kaplan, 1987; Kaplan, 1972, 1983; Martin, 1992; Purves, 1988), and numerous articles and dissertations have been written on this subject. During the 1980s, the development of research approaches, such as text linguistics and discourse analysis, helped to improve the methodological orientation of contrastive rhetoric research (Enkvist, 1987; Leki, 1991). As a result, researchers have begun to study organizational structures of both L1 and L2 written discourse more vigorously and systematically (Martin, 1992), and contrastive rhetoric has come to be defined in a broader term, encompassing more than just the organizational structures (see Connor, 1996; Ostler, 1996).

Despite the initial pedagogical aim of contrastive rhetoric, however, the insights gained by research have not been effectively translated into the practice of teaching organizational structures (Raimes, 1991; Robinson, 1993). As Kaplan (1980) once wrote, the insights generated by scientific analyses of language

I thank Ulla Connor, Akiko Fujii, Aya Matsuda, and the editors and anonymous reviewers of the Journal of Second Language Writing for their thoughtful comments on earlier versions of this article.

Correspondence and requests for reprints should be sent to Paul Kei Matsuda, Department of English, Purdue University, West Lafayette, IN 47907-1356. 
yield "interesting results" but they may not become useful to language teachers immediately because "the needs of the language analyst are quite different from the needs of the language user" (p. 59). More recently, Leki (1991) pointed out that "the immediate practical uses of the findings of contrastive rhetoric for ESL writing teachers are not altogether clear" (p. 137). Grabe and Kaplan (1989) also warned ESL writing teachers that "contrastive rhetoric does not offer a curriculum" (p. 277), although the notion "will continue to make a significant contribution to L2 curricular decisions and writing instruction" (p. 278).

The need for ESL writers to learn how to organize English written discourse still exists (Grabe \& Kaplan, 1989; Kaplan, 1988; Leki, 1991, 1992; Reid, 1989; Severino, 1993), although the way to translate research insights into classroom practice is yet to be developed. My aim in this study, then, is to develop a model of $\mathrm{L} 2$ writing that can help teachers place insights from contrastive rhetoric studies into the practice of teaching ESL writing. I begin by identifying a static theory of L2 writing that incorporates findings of early contrastive rhetoric research, and then discuss how this theory has been limiting the potential contribution of contrastive rhetoric to L2 writing pedagogy. Finally, I propose an alternative model that can guide further research and the teaching of L2 textual organization.

\section{A STATIC THEORY OF L2 WRITING}

Early in the history of contrastive rhetoric studies, some attempts were made to incorporate the insights from early contrastive rhetoric research into an approach to the teaching of ESL writing (see Raimes, 1983, 1991; Silva, 1990). The early contrastive rhetoric-based pedagogy, however, uncritically accepted what some researchers (e.g., Connor, 1996; Liebman, 1992) call "old" contrastive rhetoric, while failing to evolve with the subsequent development of "new" contrastive rhetoric research.

Viewing the problem of L2 writing essentially as the problem of negative transfer, the early pedagogical approach to textual organization, or what Raimes (1983) called "the paragraph-pattern approach" tended to focus on teaching "the particularly 'English' features of a piece of writing" (pp. 7-8). In this approach, students

copy paragraphs, analyze the form of model paragraphs, and imitate model passages. They put scrambled sentences into paragraph order, they identify general and specific statements, they choose or invent an appropriate topic sentence, they insert or delete sentences. (p. 8)

Perhaps for lack of workable alternatives, this "current-traditional" pedagogy became one of the dominant approaches in the teaching of ESL writing (Silva, 1990). However, this pedagogical approach came to be severely criticized because of its prescriptive nature and its deterministic view of the influence of 
the L2 writer's background (Leki, 1991). The criticism of this pedagogy in turn limited the potential contribution of contrastive rhetoric to the teaching of L2 writing. Underlying this early pedagogical approach to the teaching of L2 textual organization is a static theory of L2 writing. This section elaborates on the static theory and discusses its limitations.

\section{Explanations for L2 Textual Organization}

One of the important contributions that contrastive rhetoric researchers have been making is the understanding of discourse-level structures that are observed in different languages (Grabe \& Kaplan, 1989; Leki, 1991, 1992). The findings of contrastive rhetoric research have provided teachers with some insights that can guide their decisions in developing curriculum and in responding to ESL students' needs. At the very least, contrastive rhetoric suggests the need for the teachers to be aware of the differing cultural, linguistic, and rhetorical traditions that students bring with them (Leki, 1992).

Some contrastive rhetoric researchers have contributed to the teaching of ESL writing by identifying the possible sources of the apparent lack of coherence in ESL texts. The explanations that they have generated can be classified roughly into three types: linguistic, cultural, and educational explanations.

The following review is not intended to be a taxonomy of contrastive rhetoric studies per se, but a characterization of ways in which contrastive rhetoric has been incorporated into the static model of $\mathrm{L} 2$ writing. Whereas this type of classification scheme is necessarily a reductive generalization, it can nonetheless help teachers and researchers understand some of the guiding assumptions that underlie the early pedagogical theory of L2 textual organization.

The linguistic explanation emphasizes the prominence of the writer's L1 as an influencing-if not determining-factor in the L2 organizational structures (see Hinds, 1983, 1990; Kaplan, 1966; Ostler, 1987). Influenced by the Sapir-Whorf hypothesis to varying degrees, studies that support this explanation regard organizational structures of written discourse as above-sentencelevel linguistic structures (Kaplan, 1987; Martin, 1992).1 Grabe and Kaplan (1989) summarized the linguistic explanation generated by early contrastive rhetoric researchers as follows:

Writers composing in different languages [italics added] will produce rhetorically distinct texts, independent of other causal factors such as differences in processing, in age, in relative proficiency, in education, in topic, in task complexity, or in audience. (p. 264)

1The Sapir-Whorf (or Whorfian) hypothesis is the notion that human perception is affected by the language spoken by the individual. See Connor (1996, pp. 28-29) for a succinct review of the Sapir-Whorf hypothesis and its variations. 
Since the organizational structure of written text is considered as part of the linguistic structure, the linguistic explanation holds that the teaching of written English should also include the teaching of the "morphosyntax of the target language ... at the intersentential level" (Kaplan, 1988, p. 278).

The cultural explanation maintains that organizational structures are strongly influenced, if not determined, by the cultural background of the writer (see Bickner \& Peyasantiwong, 1988; Leki, 1992; Matalene, 1985; Purves, 1988; Söter, 1988). Studies that fall under this category support the view that the organizational structure of written discourse is a cultural phenomenon. Leki (1992) wrote, for example, "cultures evolve writing styles appropriate to their own histories and the needs of their societies" (p. 90). The pedagogical application of this view involves the teaching of organizational structures that fit the cultural conventions shared by the readers, because "the fact that the student knows the conventions of his or her own writing system does not mean the student understands the conventions employed in the target language" (Kaplan, 1988, pp. 296-297).

The educational explanation considers how writers acquire the patterns they use in their writing in the first place, and explains the structures of ESL texts in terms of educational backgrounds. Mohan and Lo (1985), for example, compared ESL writing instruction in Hong Kong and British Columbia, and concluded that the organizational structure in ESL text may be a result of developmental factors. Similarly, Liebman (1992) argued that prior L1 writing instruction may also be a factor influencing different aspects of writing. In this view, the ESL text may seem to be organized inappropriately because the writer has either been taught differing organizational schemata or has not mastered the organizational patterns to produce structures that are acceptable in the discourse community in which the text is placed.

These three explanations are not mutually exclusive, as some contrastive rhetoric researchers have acknowledged (i.e., Hinds, 1983; Leki, 1992; Mohan, 1986; Mohan \& Lo, 1985). At this point, little evidence exists to support the view that any one of them is most salient (Mohan, 1986; Mohan \& Lo, 1985), and researchers (e.g., Taylor \& Chen, 1991) are beginning to consider "cultural orientations toward self, others, society, and social interaction" (Connor, 1996 , p. 41) as influencing factors. However, the accumulating evidence from contrastive rhetoric research warrants the view that linguistic, cultural, and educational backgrounds have some influence on the organizational structures of ESL text, although they are by no means the only factors (see Connor, 1996; Grabe \& Kaplan, 1989).

The three major explanations for the organizational structures of ESL text come from different theoretical perspectives, leading to different conclusions about the nature of organization in ESL texts and the teaching of ESL writing. These explanations were incorporated into a static pedagogical theory of L2 writing, which has been widely used in ESL writing classrooms. This pedagogical theory provides a set of assumptions about what Silva (1990) called the elements of L2 writing: "the L2 writer," "the L1 reader," "the L2 text," "the 
contexts for L2 writing," and "the interaction of these elements in a variety of authentic ESL settings" (p. 18). The conceptual relationship among the elements of L2 writing in the existing theory is shown in Figure 1.

\section{Some Underlying Assumptions}

The static theory of L2 writing pedagogy holds a mechanistic view of the writer, which may have come from the behavioristic assumption that was dominant in oral approach and controlled composition (Silva, 1990). Under this view, the writer is not granted agency; he or she does not have the autonomy to make decisions in spite of the circumstance. Instead, the writer is seen as a "writing machine," as it were, that creates text by reproducing the pattern provided by his or her linguistic, cultural, or educational background. Take, for example, a Japanese student writing a letter to the editor of the campus newspaper about the quality of coverage on campus issues. The pedagogical theory based on this view of L2 writing explains features of the text only in terms of the influence from Japanese language, culture, or educational system. All other factors (e.g., the writer's past experience with the genre and with the particular discourse community) that might be influencing the textual features-beyond the fact that it was written as a letter to the editor-would be ignored.

Another important assumption underlying the static theory is that text is merely a linguistic code. Despite the increasing recognition of the negotiation and construction of meaning that take place both in the process of writing (e.g., Zamel, 1982) and in the process of reading (e.g., Tierney \& Pearson, 1985), the textual structure is still construed as the direct representation of the writer's mental process, which is to be decoded by the reader. For this reason, some

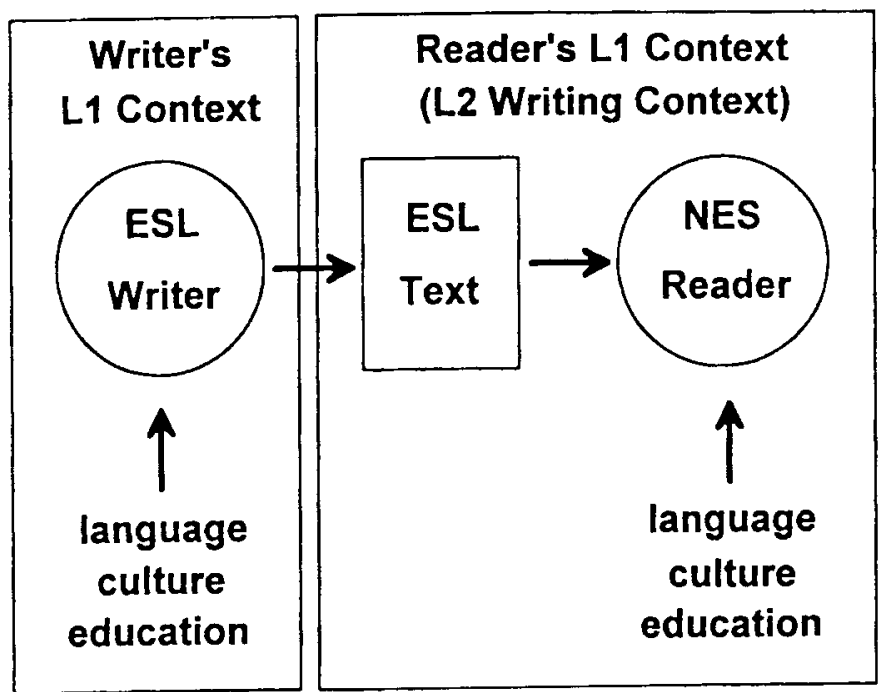

Figure 1. A Static Theory of L2 Writing 
early contrastive rhetoric researchers assumed that the examination of text alone can reveal the "thought patterns" of the writer (Kaplan, 1966, p. 4) or the "rhetorical patterns" of the L1 written discourse (Hinds, 1983, p. 186). ${ }^{2}$ However, I would argue, generalizations about the student's background that were made without consulting the student to understand his or her intentions in organizing the text does not provide useful information for the teacher.

If the text is seen as the embodiment of the schematic code prescribed by the writer's background, the reader's role is reduced to being the decoder of the schematic information along with the message. What makes communication fail in this model, then, is the discrepancy between the writer's and the reader's schematic expectations that come from differing backgrounds. The static theory would explain that the text is ineffective simply because it conforms to the typical pattern of organization in Japanese written discourse, with which NES readers are not familiar.

Finally, the most fundamental, yet least recognized assumption is the one about the context of writing. In the static model of L2 writing, the writer's and the reader's backgrounds-linguistic, cultural, and educational-are the only elements that constitute the context of writing, and they are construed as static entities-hence the term static theory-that determine the identities of the writer and the reader. Furthermore, L2 writing is expected to signify the reader's context and not the writer's. That is, the L2 writer is writing from the context with which he or she is familiar (e.g., the discourse community in his or her native country), while the Ll reader is reading from another context (e.g., the U.S. academic discourse community). The L2 text in this model is placed in the reader's context, from which the writer is excluded. In other words, the ESL writer is considered to be writing from the outside of the context of reading. Since the reader expects certain organizational structures that are commonly accepted in his or her language, culture, or educational system, the text that may be considered effective in the writer's context may still be perceived as incoherent in the reader's context.

\section{Limitations of the Static Theory}

Together, these assumptions about the writer, the reader, the text, and the context comprise the static theory of L2 writing on which the existing contrastive rhetoric-based approaches have been founded. This theory has limited the potential application of contrastive rhetoric research to the teaching of L2 writing. The assumption about the writer makes the static theory especially problematic because it denies the writer's agency. This theory assumes that ESL writers are more or less "programmed" to write in a certain way, and the lack of "appropriate" organizational structure in ESL text is considered to be the

2The notion that the textual organıation directly reflects the "thought pattern" of the writer has been denounced by many contemporary contrastıve rhetorıc researchers, including Kaplan himself, to be too deterministic. 
reflection of the lack of proper programming. In order to help the Japanese writer in the aforementioned example make her letter seem coherent to NES readers, approaches that are based on this pedagogical theory might try to "program" her properly by prescribing a typical organizational pattern of letters to the editor written in English.

The prescriptive nature of the teaching has been one of the central problems of contrastive rhetoric-based approaches. If, as the static model of L2 writing suggests, the appropriate organization of the text must conform to the reader's expectations that are determined by the static context, the view of organizational structures as "patterns" is justified, and the teaching of organizational patterns found in English-written discourse inevitably becomes the prescription of the value system of the NES writers.

Such a prescriptive application of contrastive rhetoric research has lead contrastive rhetoric-based approaches to be frowned upon by some teachers and researchers, who have characterized them as "ESL version[s] of currenttraditional rhetoric" (Silva, 1990, p. 13; cf. Grabe \& Kaplan, 1989). Indeed, many contrastive rhetoric-based approaches to the teaching of organizational structures have been reminiscent of current-traditional rhetoric, which assumes that the writer's thoughts "can be graphically displayed in discourse" (Crowley, 1990 , p. 13). Just as the adherents of current-traditional rhetoric contended that "bad writing is nothing more than outward and visible sign of bad thinking" (Campbell, 1939, p. 179), so uncritical proponents of contrastive rhetoric-based approaches assume that the organizational structure of $\mathrm{L} 2$ text is the sign of the ways of thinking that are specific to the linguistic, cultural, or educational background of the writer.

Another problem associated with the static pedagogical theory is that textual features are equated with the personal background of the ESL writer, and the writer's linguistic and cultural background is viewed as a significant part of her or his identity. Thus, the teaching of a new cultural and linguistic identitynamely, that of the English language- has been equated with the violation of the writer's personal identity. Land and Whitley (1989) argued, for instance, that to demand students to construct texts that resemble ones written by native English speakers is to ask them to "situate themselves within a particular sociopolitical context, and we respond to and judge their writing according to how accurately they are able to do so" (p. 289). For this reason, they called the pedagogical approaches based on this static theory "composition and colonization" (p. 289). These negative characterizations of one form of contrastive rhetoric-based pedagogy have led some teachers and researchers of L2 writing to dismiss contrastive rhetoric-based approaches altogether, as well as the insights generated by contrastive rhetoric research.

The teaching of organization is indeed problematic if one accepts the proposition that the organizational structure of written discourse is determined wholly by the writer's background, which constitutes his or her linguistic and cultural identity. However, the teaching of organization need not be prescriptive or 
colonizing, because organizational structure of written discourse is not determined solely by who the writer is. The decisions about the organization may be influenced by the writer's cultural, linguistic, or educational background, as the static theory may indicate, but these three are not the determining factors. The organization of the text reflects the complexity of the process of decision making that writers go through as they respond to their own perception of the particular context of writing. The process of writing, then, can be seen as the process of deciding how to respond to the context of writing.

In order to understand the complex decision-making process involved in the organization of written text, a pedagogical theory of L2 writing needs to look beyond the background of ESL writers. In other words, an alternative theory of L2 writing is needed. In the following section, I propose an alternative model of L2 writing that accounts for the complexity of factors that influence the writer in the process of organizing L2 text.

\section{A DYNAMIC MODEL OF L2 WRITING}

The graphic representation of the interrelationship among the elements within a dynamic model of L2 writing is provided in Figure 2. In this alternative model, the context of writing - which consists of all of the shaded areasincludes both the writer and the reader along with their backgrounds. Writing in this model is considered to take place in its own dynamic context, which is created as a result of the encounter of the writer and the reader - an encounter mediated through the text. The context of writing, then, is defined as the

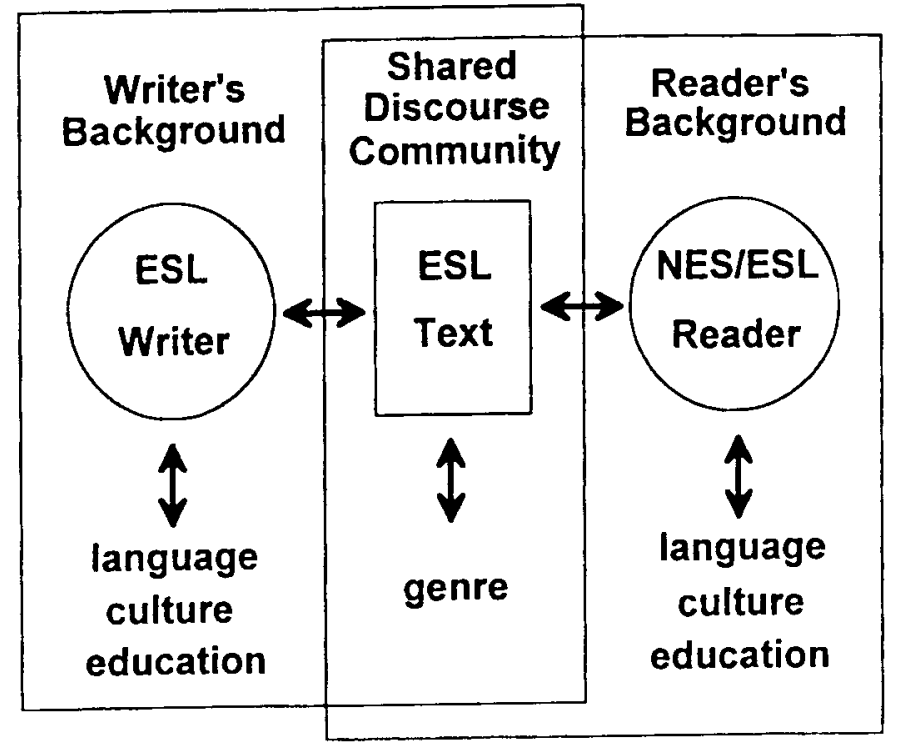

Figure 2. A Dynamic Model of L2 Writing 
dynamic environment that surrounds the meeting of the writer and the reader through the text in a particular writing situation.

Three key features of the dynamic model of L2 writing are (a) the writer's and the reader's backgrounds, (b) shared discourse community, and (c) the interaction of the elements of L2 writing within the dynamic context. In the following sections, I explain each of these features.

\section{An Expanded Conception of Backgrounds}

Placing the writer within the immediate context of writing does not remove the three explanations generated by early contrastive rhetoric studies from the picture. On the contrary, writer's and reader's backgrounds are still differentiated in this model, although they are not conflated with the context of writing as it was in the static model. In the static model, the $\mathrm{L} 1$ reader's background alone constituted the context of writing whereas in the dynamic model, the context of writing includes both the writer's and the reader's backgrounds.

In this model, however, the backgrounds of the writer and the reader include more than just language, culture, and education in a broad sense. Although these three are still probably the most salient constituents of the writer's and the reader's backgrounds, there are other, perhaps more immediate, sources of influence. The writer's decisions may also be influenced by, for example, variations within his or her native language (i.e., dialect) and culture (i.e., socioeconomic class), his or her knowledge of the subject matter, past interactions with the reader, and the writer's membership to various L1 and L2 discourse communities.

To refer back to the example of the Japanese student writing a letter to the editor, her background as a writer is much more than growing up in Japanese culture, speaking the Japanese language, or being educated in Japanese school system. Her decisions as a writer may perhaps be influenced by, for example, her experience as an editor of a high-school newspaper in Japan. Her religious view may also affect how she reacts to the particular issue. She may try to present herself more indirectly if the editor she is criticizing lives in the same residence hall as she. Furthermore, she may approach the task of writing with more confidence if she has some prior experience in writing argumentative letters for the same newspaper.

The characterization of the backgrounds of interactants is only suggestive; defining the background of the writer or the reader is probably impossible, and even useless. Although writers from similar cultural, linguistic, and educational backgrounds may exhibit some similarities in the way they write, no two people from similar backgrounds share exactly the same experience. What is important is not to arrive at a clear definition of the background of the writer and the reader, but to understand that their backgrounds are complex and flexible-varying from person to person and from time to time-and that the context of writing is also dynamic.

Because of the possible diversity of the backgrounds even among writers and readers from similar linguistic, cultural, and educational traditions, a similar 
process of negotiation may occur between an ESL writer and an ESL reader or between an NES writer and an NES reader. ${ }^{3}$ For instance, the ESL writer who has had ample exposure to the linguistic and rhetorical conventions of the target language may exhibit the ability to compose a letter more similar in quality to those written by the NES writer than ones written by other ESL writers. Conversely, the editor may have been exposed to many ESL texts and thus be able to tolerate a wider variety of textual features than average NES readers. It is also possible that the editor is an ESL reader, in which case he or she may react differently toward particular ESL errors (see Kobayashi, 1992).

\section{The Shared Discourse Community}

Unlike the static model, which conflated the reader's background and the discourse community in which the text was placed, the dynamic model sees the discourse community as shared by both the writer and the reader. The shared discourse community is the space that surrounds the text, which is placed at the intersection of the backgrounds of the writer and the reader. According to Swales (1990), a discourse community is a community that has, among other things, "a broadly agreed set of common public goals" (p. 24) and "mechanisms of intercommunication among its members" (p. 25). For the Japanese writer in my example, the campus newspaper acts as the mechanism which serves the community by disseminating potentially useful or important information for students, faculty, and staff members, and-to a lesser extent-facilitating discussions and communication among them by providing sections such as letters to the editor and classified ads.

As a member of the discourse community, the Japanese writer shares with her readers-and with other writers-"one or more genres" and "specific lexis" that are used for the "communicative furtherance of [the community's] aims" (Swales, 1990, p. 26). In this case, the student is using the genre of letter to the editor (or what is acknowledged in the particular discourse community as such) to communicate her view on the way the communication mechanism (i.e., editorial section of the newspaper) is serving the shared goals of the discourse community.

Before she can use the genre effectively, however, she still has to acquire "a suitable degree of relevant content and discoursal expertise" (Swales, 1990, p. 27; see also Bazerman, 1985; Berkenkotter, Huckin, \& Ackerman, 1988) just as any new member of the community does (Bartholomae, 1985; Bizzell, 1982a, 1982b), regardless of his or her linguistic, cultural, or educational background. However, it is important to note that, in the proposed model, each writer's or

\footnotetext{
3Since both the writer and the reader can be either NES or ESL speaker, this dynamic model of writing may also be applicable to the teaching of $\mathrm{Ll}$ writing. Although the way the context of writing influences L1 and L2 textual organization will be different, the way and the degree of the difference need to be determined through empirical research. For my realization of the potential inclusiveness of this model, I am especially indebted to Margie Berns.
} 
reader's expertise as a member of the community influences the area of the shared discourse community. The writer can therefore negotiate his or her access to the discourse community by becoming familiar with the discourselevel conventions. The Japanese writer may increase the chance of having her letter published by studying the ways in which conventionalized discourse features are used by other members of the community.

Although these global conceptions of the discourse community are useful, the shared discourse community does not simply exist "out there." Rather, the shared discourse community is "local, historical, and interactive" (Casanave, 1995 , p. 88); they are created or modified through the encounter of the writer and the reader who have differing levels of discourse expertise as well as different backgrounds. In other words, the reader can also help to enlarge the shared area by growing accustomed to the presence of the text which embodies differing assumptions, experiences, and levels of discourse expertise.

\section{Bidirectionality of the Interrelationship}

Another key feature of the dynamic model of L2 writing is the bidirectional nature of the interrelationship among its elements. The interaction of the differing backgrounds not only constructs the shared discourse community, but also transforms the writer's and reader's backgrounds. For this reason, the context of writing in this model is more than the sum of the writer's and the reader's backgrounds.

The writer is also capable of deviating from the influences of his or her background as well as transforming it by changing the way he or she perceives and relates to it. The Japanese student's experience of participating in the discourse community of the campus newspaper may influence the way she writes later in other discourse communities, such as local newspapers in her home town, thus contributing to the transformation of the conventions of those communities. In other words, the experience of participating in a new discourse situation becomes part of the writer's background.

In this model, ESL students are not solely responsible for becoming enculturated into existing discourse communities. The reader may also experience a similar process of negotiating his or her own background as a result of reading the Japanese student's text. Casanave (1995), for example, demonstrated how professors came to perceive their own discourse differently as a result of interactions with students from backgrounds that were different from their own. Having participated in the discourse with the Japanese writer, the reader in my example may have gained a new perspective with which to reevaluate and transform his or her own background.

Furthermore, the presence of L2 text can lead to the transformation of L1 discourse into a more pluralistic one, as Land and Whitley (1989) argued. Prior (1995) also showed that students, through their participation in local academic discourse communities, contributed to the dialogical construction of genres within those communities. Because the Japanese student's participation in the 
shared discourse community (i.e., writing a letter to the editor) adds to the network of texts within the discourse community, it may eventually influence the existing genre conventions.

The bidirectionality also applies to the text. The text can be seen as a medium through which the context of writing is negotiated rather than as a codified body of meaning that is structured according to patterns prescribed by the writer's background. As Kaplan (1991) wrote:

A text has no reality until it is instantiated by a receptor; that is, the meaning of the text lies not in the text itself, but in the complex interaction between the author's intent and his/her performance ability to encode that intent, and the receptor's intent and his/her performative ability not only to decode the author's intent but to mesh his/her own intent with the author's. (p. 203)

The text, then, creates a virtual world, as it were, in which the writer and the reader meet each other and construct a shared social reality (Brandt, 1986). To serve this purpose adequately, the organization of text must reflect the writer's understanding of the complexity of the context of writing.

With this view of text, the writer needs to learn more than just the organizational pattern preferred by the reader or the accepted genre conventions in the shared discourse community. In order to mediate the differing backgrounds that the writer and the reader bring to the context of writing, the text must also reflect the writer's understanding of the reader's background and the genres in the discourse community shared by the writer and the reader. The Japanese writer in the previous example needs to shape her letter according to her understanding of the readers (e.g., students, faculty, and staff) and their backgrounds (e.g., language, culture, education, relationship with the writer), as well as the genre (e.g., letter to the editor), and her own awareness of the ongoing discussions about the subject in the particular newspaper.

Teaching ESL students to organize L2 writing, then, does not mean imposing on them the cultural values of native English speakers or prescribing patterns. Rather, it should be considered as a way of raising ESL students' awareness of various factors that are involved in structuring the text, including the reader's expectations of certain organizational patterns. In other words, the act of organizing the text is not the same as using prescribed patterns or genre conventions that fit the subject, but should be seen as the process of complex decision making, which involves an understanding of the dynamic nature of the context of writing.

\section{IMPLICATIONS}

What I have presented is an attempt to construct a model that may be developed into a more empirically grounded theory of L2 writing pedagogy. At this point, I submit this model for further scrutiny, because not enough empirical 
evidence exists to help define the relationship between text and context, or to differentiate processes of $\mathrm{L} 1$ and $\mathrm{L} 2$ writing. This is not to say that writing in $\mathrm{L} 1$ and $\mathrm{L} 2$ are essentially the same. The difference between $\mathrm{L} 1$ and L2, however, lies not in what are involved in the general process of organizing a piece of writing but in how and to what degree elements of the dynamic model interact with one another. After all, even L1 writers may come from diverse cultural, educational, and sociolinguistic backgrounds. The difference needs to be determined through empirical studies that are conducted in a variety of authentic contexts and with L1 and L2 writers and readers from various backgrounds. Models of L2 writing such as this one can play a role in designing empirical studies and in interpreting their results.

The proposed model is offered as a heuristic, a tool for thinking about the dynamic nature of the context of writing and the complexity of decisionmaking processes that are involved in the construction of L2 text. It is my hope that this model will facilitate further inquiry into the process of organizing L2 text. As a heuristic, the model raises more questions than it answers. For example:

1. How does the L2 textual organization reflect the writer's understanding of the context of writing?

2. What types of textual features are used in the process of negotiating the context?

3. What is involved in the decision-making process that $\mathrm{L} 2$ writers go through as they organize their texts? How is the process reflected in the textual features?

4. How do experienced and inexperienced writers use the text differently to establish and develop the shared discourse community?

5. How do answers to these questions differ between L1 writers and L2 writers?

To answer these questions, contrastive analysis of written discourse in itself will not be sufficient. Organizational structures of L2 text should be analyzed in context; that is, in light of the writer's mental representation of the context of writing, the reader's actual reactions to the text, and the outcome of the interaction of the two. One way to yield such understanding may be to combine discourse analysis and qualitative analysis of the writing and reading processes through interview-based research methods. Context-sensitive text analysis, as proposed by Huckin (1992), is especially useful for this purpose.

The dynamic model of $\mathbf{L} 2$ writing also has some implications for the teaching of L2 textual organization. Because an effective organization of text must reflect the decisions that the writer makes based on his or her perception of the context of writing, the teaching of organization necessarily involves the teaching of the awareness of the context of writing (see Liebman, 1988, for an example of awareness-raising pedagogy). 
Students need to learn how to negotiate the context of writing by actually experiencing the process. For this purpose, each writing assignment needs to be placed in a real context of writing, involving a discourse community shared with real readers. Writing assignments such as asking students to write a critical review of one another's essay, and then to share it with the whole class, including the author of the essay, allow the writer to see how the intended readers react to his or her text and how other people approach the same task.

The teacher's responses to students' writing can foster the same goal by emphasizing the importance of the awareness of the context of writing, and of the negotiation that occurs at the intersection of the writer's and the reader's backgrounds. The teacher who assigned the review of a classmate's essay might express how she might feel about the directness of the criticism if she were the author of the essay.

Evaluation of organization might include considering the possible reactions of the intended reader. The teacher might also consider how the writer of the review incorporated the responses from the author of the essay and other classmates in revising the review. Only by taking into consideration the context in which the student intended to write, can the teacher accurately evaluate the effectiveness of the organizational structure of L2 text in negotiating the context.

The study of organization in written discourse has been, and will continue to be, an important part of L2 writing research. Pedagogical implications of contrastive rhetoric studies should not be dismissed because of the problems with the early attempts to apply the findings of contrastive rhetoric research. Because textual organization is one of the areas with which ESL students have most difficulties, it needs to be taught in ESL writing classrooms, but it needs to be taught in ways that are informed by an appropriate theory of L2 writing.

\section{REFERENCES}

Bartholomae, D. (1985). Inventing the university. In M. Rose (Ed.), When a writer can't write: Studies in writer's block and other composing problems (pp. 134-165). New York: Guilford Press.

Bazerman, C. (1985). Physicists reading physics: Schema-laden purposes and purpose-laden schema. Written Communication, 2, 3-24.

Berkenkotter, C., Huckin, T. N., \& Ackerman, J. (1988). Conventions, conversations, and the writer: Case study of a student in a Ihetoric Ph.D. progrann. Research in the Teaching of English, $22,9-44$.

Bickner, R., \& Peyasantiwong, P. (1988). Cultural variation in reflective writing. In A. C. Purves (Ed.), Writing across languages and cultures: Issues in contrastive rhetoric (pp. 160-174). Newbury Park, CA: Sage.

Bizzell, P. (1982a). Cognition, convention, and certainty: What we need to know about writing. Pre/Text, 3, 213-241.

Bizzell, P. (1982b). College composition: Initiation into the academic discourse community. Curriculum Inquiry, 12, 191-207.

Brandt, D. (1986). Toward an understanding of context in composition. Written Communication, 3, 139-157. 
Campbell, O.J. (1939). The failure of freshman English. English Journal: College Edition, 28, 177-185.

Casanave, C.P. (1995). Local interactions: Constructing contexts for composing in a graduate sociology program. In D. Belcher \& G. Braine (Eds.), Academic writing in a second language: Essays on research and pedagogy (pp. 83-110). Norwood, NJ: Ablex.

Connor, U. (1996). Contrastive rhetoric: Cross-cultural aspects of second-language writing. New York: Cambridge University Press.

Connor, U., \& Kaplan, R.B. (Eds.). (1987). Writing across languages: Analysis of L2 text. Readings, MA: Addison-Wesley.

Crowley, S. (1990). The methodical memory: Invention in current-traditional rhetoric. Carbondale: Southern Illinois University Press.

Enkvist, N.E. (1987). Text linguistics for the applier: An orientation. In U. Connor \& R.B. Kaplan (Eds.), Writing across languages: Analysis of L2 text (pp. 23-43). Reading, MA: AddisonWesley.

Grabe, W., \& Kaplan, R.B. (1989). Writing in a second language: Contrastive rhetoric. In D.M. Johnson \& D.H. Roen (Eds.), Richness in writing: Empowering ESL students (pp. 263-283). White Plains, NY: Longman.

Hinds, J. (1983). Contrastive rhetoric: Japanese and English. Text, 3, 183-195.

Hinds, J. (1990). Inductive, deductive, quasi-indictive: Expository writing in Japanese, Korean, Chinese, and Thai. In U. Connor \& A.M. Johns (Eds.), Coherence in writing: Research and pedagogical perspective (pp. 89-260). Alexandria, VA: TESOL.

Huckin, T.N. (1992). Context-sensitive text analysis. In G. Kirsch \& P.A. Sullivan (Eds.), Methods and methodology in composition research (pp. 84-104). Carbondale: Southern Illinois University Press.

Kaplan, R.B. (1966). Cultural thought patterns in inter-cuitural education. Language Learning, 16, $1-20$.

Kaplan, R.B. (1972). The anatomy of rhetoric: Prolegomena to a functional theory of rhetoric. Philadelphia: Center for Curriculum Development.

Kaplan, R.B. (1980). On the scope of linguistics, applied and non-. In R.B. Kaplan (Ed.), On the scope of applied linguistics (pp. 57-66). Rowley, MA: Newbury.

Kaplan, R.B. (Ed.). (1983). Annual review of applied linguistics (Vol. 3).

Kaplan, R.B. (1987). Cultural thought patterns revisited. In U. Connor \& R.B. Kaplan (Eds.), Writing across languages: Analysis of L2 text (pp. 9-21). Reading, MA: Addison-Wesley.

Kaplan, R.B. (1988). Contrastive rhetoric and second language learning: Notes toward a theory of contrastive rhetoric. In A. Purves (Ed.), Writing across languages and cultures: Issues in contrastive rhetoric (pp. 275-304). Newbury Park, CA: Sage.

Kaplan, R.B. (1991). Concluding essay: On applied linguistics and discourse analysis. Annual Review of Applied Linguistics, 11, 199-204.

Kobayashi, T. (1992). Native and nonnative reactions to ESL compositions. TESOL Quarterly, 26, 81-112.

Land, R. E., Jr., \& Whitley, C. (1989). Evaluating second language essays in regular composition classes: Toward a pluralistic U.S. thetoric. In D.M. Johnson \& D.H. Roen (Eds.), Richness in writing: Empowering ESL students (pp. 284-293). New York: Longman.

Leki, I. (1991). Twenty-five years of contrastive rhetoric: Text analysis and writing pedagogies. TESOL Quarterly, 25, 123-143.

Leki, I. (1992). Understanding ESL writers: A guide for teachers. Portsmouth, NH: Boynton/Cook.

Liebman, J. (1988). Contrastive rhetoric: Students as ethnographers. Journal of Basic Writıng, 7, 6-27.

Liebrnan, J.D. (1992). Toward a new contrastive rhetoric: Differences between Arabic and Japanese rhetorical instruction. Journal of Second Language Writing, 1, 141-165.

Martin, J.E. (1992). Towards a theory of text for contrastive rhetoric: An introduction to issues of text for students and practitioners of contrastive rhetoric. New York: Peter Lang. 
Matalene, C. (1985). Contrastive rhetoric: An American writing teacher in China. College English, 47, 789-807.

Mohan, B.A. (1986). On evidence for cross-cultural rhetoric. TESOL Quarterly, 20, 358-361.

Mohan, B.A., \& Lo, W.A-Y. (1985). Academic writing and Chinese students' transfer and developmental factors. TESOL Quarterly, 19, 515-534.

Ostler, S.E. (1987). English in parallels: A comparison of English and Arabic prose. In U. Connor \& R.B. Kaplan (Eds.), Writing across languages: Analysis of L2 text (pp. 169-185). Reading, MA: Addison-Wesley.

Ostler, S.E. (1996, March). Contrastive rhetoric: Myths, facts, and pedagogy. Paper presented at the 30th Annual TESOL Conference, Chicago.

Prior, P. (1995). Redefining the task: An ethnographic examination of writing and response in graduate seminars. In D. Belcher \& G. Braine (Eds.), Academic writing in a second language: Essays on research and pedagogy (pp. 47-82). Norwood, NJ: Ablex.

Purves, A.C. (1988). Introduction. Writing across languages and cultures: Issues in contrastive rhetoric (pp. 9-21). Newbury Park, CA: Sage.

Raimes, A. (1983). Techniques in teaching writing. New York: Oxford University Press.

Raimes, A. (1991). Out of the woods: Emerging traditions in the teaching of writing. TESOL Quarterly, 25, 407-430.

Reid, J.M. (1989). English as second language composition in higher education: The expectations of the academic audience. In D.M. Johnson \& D.H. Roen (Eds.), Richness in writing: Empowering ESL students. New York: Longman.

Robinson, J.H. (1993, April). Contrastive rhetoric and the revision process for East Asian students. Paper presented at the 27th Annual TESOL convention, Atlanta.

Severino, C. (1993). The "doodles" in context: Qualifying claims about contrastive rhetoric. The Writing Center Journal, 13, 44-61.

Silva, T. (1990). Second language composition instruction: Developments, issues and directions in ESL. In B. Kroll (Ed.), Second language writing: Research insights for the classroom (pp. 11-23). New York: Cambridge University Press.

Söter, A.O. (1988). The second language leamer and cultural transfer in narration. In A. Purves (Ed.), Writing across languages and cultures: Issues in contrastive rhetoric (pp. 177-205). Newbury Park, CA: Sage.

Swales, J.M. (1990). Genre analysis: English in academic and research settings. New York: Cambridge University Press.

Taylor, G., \& Chen, C. (1991). Linguistic, cultural, and subcultural issues in contrastive discourse analysis: Anglo-American and Chinese scientific texts. Applied Linguistics, 12, 319-336.

Tierney, R.J., \& Pearson, P.D. (1985). Toward a composing model of reading. Reading Research Quarterly, 9, 135-147.

Zamel, V. (1982). Writing: The process of discovering meaning. TESOL Quarterly, 16, 195-209. 
